\title{
Beyond Rational Choice: International Trade Law and The Behavioral Political Economy of Protectionism
}

\author{
Anne van Aaken* and Jürgen Kurtz ${ }^{* *}$
}

\begin{abstract}
The classic political economy of trade models state behavior on the international plane by reference to the formation of domestic interests. Voters, interest groups, and politicians are rational actors in this model, pursuing their economic preferences without cognitive or motivational distortions. This article questions the sufficiency of the rational choice model in the formation of contemporary trade policy. Starting from the classic political economy story, this article explores real-world deviations from rationally expected outcomes by drawing on cognitive psychology. Using both theoretical and empirical analysis, we seek to identify key distortions that can better explain voter and politician behavior in the current trade wars. We begin with loss aversion in that individuals have asymmetrical attitudes towards gains and losses. Rising inequality within the rich world amounts to a perceived relative loss particularly for middle-class citizens. Combined with the absolute rise of equality between countries, this can trigger a double loss frame-both as an individual loss and a national loss - that can profoundly shape anti-trade preferences in certain countries. Framing trade as a security threat also invokes powerful hawkish biases. Lastly, the availability bias can be provoked by social media mechanisms making people tend to focus on particular risks and overweight their import.
\end{abstract}

\section{INTRODUCTION}

State behavior to foreign trade is traditionally explained by rationalist approaches, assuming a two-level game. The classic political economy account models the behavior of states or their governments on the international plane by reference to the formation of domestic interests within a given state. Endogenous policy formation treats interest groups (and sometimes voters) as participants in a competition for political favors, which are meted out by politicians pursuing their own self-interest. In particular, rational choice theorists emphasize the concentrated losses (and thus lobbying incentives)

* Alexander von Humboldt Professor for Law and Economics, Legal Theory, Public International Law and European Law, Director, Institute of Law and Economics, University of Hamburg, email: anne.van.aaken@uni-hamburg.de.

** Professor of International Economic Law, European University Institute; Professor, University of Melbourne (on leave), email: Jurgen.Kurtz@eui.eu.

(C) The Author(s) 2019. Published by Oxford University Press. All rights reserved. This article is published and distributed under the terms of the Oxford University Press, Standard Journals Publication Model (https://academic.oup.com/journals/pages/open_access/funder_policies/chorus/ standard_publication_model) 
to import-competing industry in a shift towards a policy of freer trade. In contrast, the relatively minor benefits to individual consumers are unlikely to motivate those dispersed actors to bind together and lobby for a policy of free trade. On the other hand, firms that seek to export to foreign markets have inentives to lobby for liberalization. Voters, interest groups, and politicians are viewed as rational actors in this model, pursuing their economic preferences without cognitive or motivational distortions. Trade policy is thus understood as an outgrowth of a political process that does not necessarily give rise to aggregate welfare maximization.

This article questions the sufficiency of the rational choice model generally and in the formation of contemporary trade policy specifically. It is difficult to explain the trade-related aspects of BREXIT and the Trump Administration's turn to destabilising tariffs in the guise of its 'America First ${ }^{\text {' }}$ policies purely on the basis of the rational voter paradigm. Rather, we propose to explore the added explanatory potential of behavioral economics and behavioral political economy. Although behavioral economics has revolutionized huge parts of economics, it is rarely used in the political economy of trade. Yet psychological experimental research shows that in contrast to the expected utility model based on material preferences used in economics and international relations theory, actors are only boundedly rational and systematically have other-regarding preferences (both positive and negative). Decisions also depend on contexts and framing effects that depart from the rationalist axiom of 'descriptive invariance'. Prospect theory in particular describes the manner in which people choose between probabilistic alternatives involving risk. Typically, decisions will vary depending on how circumstances are framed and presented, either as a positive or negative deviation from the status quo. Most fundamentally, individuals are loss averse with an asymmetrical attitude towards gains and losses. Loss aversion seems especially promising in understanding the impact of claims of trade deficits in shaping the Trump administration trade policies towards China and other major economic actors like the European Union. It is striking here that much of the debate on current trade and investment policy is framed around the security (and thus relative status) of some countries (especially the USA vis-à-vis China) based on geopolitical shifts further triggering loss aversion. There are additional psychological kinks in rationality that are systematically substantiated by scientific experiments in cognitive psychology. For example, under the availability bias, people tend to think that risks are more serious when an incident is readily called to mind. Availability of information - such as the so-called 'China shock' after the 2001 Chinese accession to the WTO and now the 'Made in China 2025' announcement-can have broader cognitive effects on decisions. Of course, protectionist outcomes can disrupt supply chains and prove costly to consumers and/or workers, but the consequences are not immediately crystallized and thus might be neglected.

Starting from the political economy story of trade, this article explores real-world deviations of rationally expected outcomes by drawing on cognitive psychology. To be

1 See e.g. Trump Twitter: 'In trade military and EVERYTHING else it will be AMERICA FIRST! This will quickly lead to our ultimate goal: MAKE AMERICA GREAT AGAIN!' of 23.05.2016, https://twitter.com/ realDonaldTrump/status/734742416494845952. 
sure, protectionism is not a new phenomenon. ${ }^{2}$ But we are witnessing dramatic, even unprecedented, shifts in trade policies in some countries not seen since the Great Recession. We propose to explore the manner in which behavioral economics and psychology can offer a framework to better explain the drivers of the contemporary and sudden outbreak of protectionism. Beyond the contemporary setting, its insights may also more generally be applied to trade policy, explaining who is likely to support protectionism (not just those who lose in economic terms), why (including sociotropic preference formation and out-group hostility), and under what scope conditions loss aversion kicks in (not least rising inequality within countries and rising equality between countries).

The article proceeds as follows. In Part II, we outline the classical political economy of trade policy based on the rational choice model and especially its key assumptions such as motivational rationality, the nature of utility gains and losses from freer trade (from the perspective of individuals), and amelioration of trade-induced dislocation effects (whether organically or through targeted policies). Part III then identifies a framework of select insights of behavioral economics which may be relevant for the formation of trade policy but call into question many of the underlying assumptions of the rational choice account. Part III also offers a targed discussion of the unit of analysis problem, as we shift beyond the state as a unitary actor. Part IV applies these general insights to the specific question of formation of current trade policy using both analytical tools and where appropriate, empirical data to contextualize and probe key claims (on questions such as the impact of framing and availability bias). Part V briefly defines scope conditions under which biases and heuristics may lead to protectionism, and makes preliminary suggestions on how international trade law might better take account of bounded rationality.

\section{CLASSICAL POLITICAL ECONOMY OF TRADE POLICY: INSIGHTS AND LIMITATIONS OF PUBLIC CHOICE THEORY}

Many of the original legal constraints in international trade law can be understood through the prism of public choice theory. ${ }^{3}$ As a starting point, a public choice account of domestic regulation contests the notion that government is necessarily a benevolent maximizer (servant) of social welfare. Public officials are viewed instead as politically sophisticated actors pursuing rational (self-interested) agendas, especially the maximization of political support in order to increase their chances for re-election. Public choice theory places a significant weight on the role played by interest groups in the formation of regulatory policy. ${ }^{4}$ In the trade context, theorists emphasize the concentrated losses that are incurred in a shift towards a policy of free trade. The import-competing industry has abundant incentives to lobby incumbent governments

2 Anne O. Krueger, 'Wilful Ignorance: The Struggle to Convince Free Trade Sceptics', 3 WorLd Trade REVIEW 483 (2004).

3 Of course, there is also a long tradition in explaining economic nationalism in international political economy; see only Robert Gilpin, 'The Politics of Transnational Economic Relations', 25(3) International Organization 398 (1971).

4 Gene Grossman and Elhanan Helpman, 'Protection for Sale', 84(4) American Economic Review 833 (1994), at 848 . 
to entrench systems of trade protection in order to maintain market share. The concentrated job losses that flow from a move towards free trade in a given industry may also align labor interests with that of those industry groups seeking protection. ${ }^{5}$ In contrast, the relatively minor benefits to individual consumers, although huge in the aggregate, are unlikely to motivate dispersed consumers to bind together and lobby for a policy of free trade. ${ }^{6}$ With this collective action problem, domestic policy outcomes may systematically and disproportionately prioritize the welfare of the few (importcompeting industry) over the welfare of the many (consumers in the importing state). Moreover, a public choice account challenges a statist model of the formation of foreign economic policy. Under this static account, executive institutions and officials are understood as independent players in international settings, pursuing policies to serve national objectives with limited concessions to domestic political groups. Public choice theorists instead will argue that international relations on trade issues are best seen as a 'two-level game" involving simultaneous negotiations and concessions at both the intranational (between domestic interest groups and elected officials) and international (between governments) arenas. ${ }^{8}$

Of course, other factors may impact the decisional calculus and tilt it in a direction at odds with what these various facets of public choice theory would predict. Trade protection may motivate domestic producers downstream (who incorporate the foreign good as an intermediate input) to become politically active against import barriers. ${ }^{9}$ That said, recent empirical evidence suggests a different causal direction, depending on levels of industry concentration. Supporting a theoretical model of 'cascading protection, ${ }^{10}$ that evidence suggests that granting trade protection to intermediate manufacturers leads instead to demands for protection by downstream users. ${ }^{11}$ Of course, not all industries are equally well organized. Domestic industries that are made up of a large number of small producers may have difficulty overcoming the transaction costs and

5 Robert Baldwin, 'The Political Economy of Trade Policy: Perspectives of Economists and Political Scientists', in Robert Feenstra, Gene Grossman, and Douglas Irwin (eds), 'The Political Economy of Trade Policy: Papers in Honor of Jagdish Bhagwati' (Cambridge, MA: MIT Press, 1996) vol. 1, 147-175 at 162.

6 Ibid.

7 Robert D. Putnam, 'Diplomacy and Domestic Politics: The Logic of Two-Level Games', 42 International Organization 427 (1988), at 460.

8 For the application of this theory in cooperative and non-cooperative tariff-setting games, see Gene Grossman and Elhanan Helpman, 'Trade Wars and Trade Talks', 103(4) Journal of Political Economy 675 (1995).

9 See Grossman and Helpman, above n 4, at 849 (noting that 'the most serious political opposition to protection arises when higher prices stand to harm other producer interests downstream').

10 Robert Feinberg and Seth Kaplan, 'Fishing Downstream: The Political Economy of Effective Administered Protection', 26(1) Canadian Journal of Economics 150 (1993); Michael P. Leidy and Bernard Hoekman, 'Cascading Contingent Protection', 36 European Economic Review 883 (1992).

11 Drawing on trade remedy petitions over the 1988-2013 period, Ebahar and $\mathrm{Zi}$ find that for the USA, 'upstream protection leads to downstream petition for protection'. Interestingly, the authors replicated their analysis for the EU but found no such evidence for cascading protection suggesting that the critical difference is that in the EU (unlike the USA) trade remedy investigations explicitly take downstream effects into account. Aksel Erbahar and Yuan Zi, 'Cascading Trade Protection: Evidence from the U.S.', 108 Journal of International Economics 274 (2017), at 289. 
free-rider problems associated with efforts to influence the political process. ${ }^{12}$ Yet generally speaking, public choice theory holds that there is a constant and structural bias towards protectionism in the formation of trade policy, at least for states whose political ordering allows for lobbying by organized and affected interests. ${ }^{13}$

Trade agreements in turn enable a government to 'tie its hands' in the face of such concerted lobbying by vested interests and give up its ability to grant protection to domestic goods (and their manufacturers). ${ }^{14}$ In the General Agreement on Tariffs and Trade 1947, quantitative restrictions on the import (or export) of goods are prohibited. ${ }^{15}$ Tariffs - taxes on foreign goods imposed at the border-were bound in schedules with members prevented from increasing these bound tariff rates. ${ }^{16}$ Moreover, a further political economy dimension (designed to overcome the entrenched resistance of import-competing industry) justifies this softer approach on tariffs vis-à-vis the hard ban on quotas. Their quantifiable and divisible nature made reduction relatively easy over time, an important dimension given the political importance of achieving a base level of reciprocity of concessions among the membership. ${ }^{17}$ It is important here to be mindful of the important role of trade agreements in mobilizing export-orientated firms who will lobby for liberalization (if offered access to foreign markets) and thereby counter-balance the lobbying power of the import-competing industry. A reciprocal exchange of concessions between states is therefore fundamental in convincing a variety of domestic interests of the overall benefits of trade liberalization. ${ }^{18}$ In successive and periodic negotiating rounds, ${ }^{19}$ members would agree to reduce their tariff rates and any such reduction would then be required to be extended to all other member states via the most favored nation (MFN) principle. ${ }^{20}$

Generally speaking, domestic taxes and regulations are fully permitted in the GATT subject only to the (negative) condition that they are not protectionist devices that

12 Alan Sykes, 'Public versus Private Enforcement of International Economic Law: Standing and Remedy', 34 Journal of Legal Studies 631 (2005), at 647.

13 The qualification here goes to authoritarian states organized on non-democratic lines. One might imagine that the leadership of such states is less likely to be influenced by the short-term views of a small number of affected domestic interests. But even here, some political scientists have suggested that such states are not entirely immune from political pressures. There is the argument that 'such leaders must still be concerned about the possibility of losing political power through military coups, riots, and mass demonstrations touched off by policies unpopular with various economic and social groups'. See Baldwin, above n 6, at 159. For a political economy account where trade agreements are motivated by the desire of governments to commit vis-à-vis domestic lobbies, see Giovani Maggi and Andres Rodriguez-Clare, 'A Political Economy Theory of Trade Agreements', 97 (4) The American Economic Review 1374 (2007).

15 GATT, Article XI.

16 Ibid., Article II.

17 Bernard Hoekman and Michel Kostecki, The Political Economy of the World Trading System: The WTO and Beyond, 2nd ed. (Oxford: Oxford University Press, 2001) 25-33.

18 Robert Hudec, “Like Product”: The Differences in Meaning in GATT Articles 1 and III', in Thomas Cottier, Petros Mavroidis, and Patrick Blatter (eds.), Regulatory Barriers and the Principle of Non-Discrimination in World Trade Law (Ann Arbor: University of Michigan Press, 2000) vol. 1, 101-123 at 108-109.

19 See Hoekman and Kostecki, above n 18, at 101-102.

20 GATT, Article I. 
would distort the bargain on tariff reductions. ${ }^{21}$ Importantly then, this is a system that allows for significant heterogeneity in regulatory and redistributive conditions and experimentation including on questions of the adverse impact of trade liberalization. The flexibilities within the system enable GATT members, on first principles, to adjust their engagement with the system in times of significant political and societal pressure. ${ }^{22}$ In fact, John Ruggie has argued that the GATT's bargain of 'embedded liberalism'with trade liberalization embedded against extensive flexibilities comprising a subset of shared social purposes among the membership — has been essential to the temporal resilience of state commitment to the trade law regime in times of pressure such as the onset of economic and political turmoil in the 1970 s. $^{23}$ Complementary accounts trace the impact of increased international interdependence in shaping the trade policy preferences of industries in this troubled period. Helen Milner argued that growth in exports and patterns of global intra-firm trade in the 1970s (with a focus on French and American industries) raised the costs of protection for internationally orientated firms who therefore resisted seeking protection even in that period of serious import competition. ${ }^{24}$ Given this historical backdrop and especially increased levels of interdependence in the global economy, it seems surprising that the contemporary period is characterized by such sharp resort to protectionism in some states. This naturally raises the question of the sufficiency of the explanatory value of classic economics and political economy in explaining the outbreak of protectionism in this turbulent period.

From an economic perspective, there is a strong case for the constraints found on border protection in the trade law system, especially MFN treatment towards tariffs on trade in goods. The economic consequences of tariffs as a form of discriminatory border tax levied only on imported goods are well understood. Tariffs distort the working of the price mechanism with both global and domestic efficiency implications. Different tariff discrimination among countries causes a shift in resources contrary to principles of comparative advantage. Demand for a given good dependent on the pricing mechanism shifts from efficient producers in a country subject to a high tariff rate to less efficient producers who are favored by a low tariff rate. An MFN principle of equal tariffs for every foreign country provides for a more efficient allocation of resources than would be the case if discrimination is practiced. ${ }^{25} \mathrm{On}$ an individual countrylevel, the distortive effects of tariff discrimination are likely to lead to higher cost imports. An MFN policy

21 Under GATT Article III(1), internal taxes or regulations 'should not be applied to imported or domestic products so as to afford protection to domestic production. These domestic policy tools if targeted at foreign goods can, of course, be simple substitutes for border (tariff) protection. Ibid., Article III.

22 See generally Simon Schropp, Trade Policy Flexibility and Enforcement in the WTO: A Law and Economics Analysis (Cambridge: Cambridge University Press, 2009).

23 John Ruggie, 'Embedded Liberalism and Postwar Economic Regimes', in John Ruggie (ed.), Constructing the World Polity: Essays on International Institutionalization (London: Routledge, 1998) 62-84.

24 Helen Milner, 'Resisting the Protectionist Temptation: Industry and the Making of Trade Policy in France and the United States During the 1970s', 41 International Organization 639 (1987), at 664.

25 An alternative theoretical proposition would position trade law as restraining terms-of-trade manipulation. Yet even here, the goal is ultimately one of efficiency (at least in global allocation of resources). Donald Regan, 'What Are Trade Agreements for? Two Conflicting Stories Told by Economists, with a Lesson for Lawyers', 9(4) Journal of International Economic Law (2006) 951-988. 
allows a country to buy from the lowest cost and efficient supplier with consequent welfare-enhancing effects for individual consumers.

Critically however, classical trade theory acknowledges that trade will yield losers within a state. Import competition may displace domestic industries, and if so, some workers will lose their livelihoods. On first principles, the shift to (greater) liberalization cannot then be understood simply as one of Pareto optimality. In fact, the level of aggregate gains seems to become smaller as trade liberalization tackles progressively lower barriers. Rodrik has argued for instance that the 'redistributive effects of liberalization get larger and tend to swamp the net gains as the trade barriers in question become smaller. ${ }^{26}$ This seems to be borne out by recent empirical research, for instance, on the new USA-Mexico-Canada Agreement (USMCA) which suggest that key provisions in the treaty will generate 'modest aggregate gains in terms of welfare, mostly driven by improved goods market access, with a negligible effect on real GDP'. ${ }^{27}$ This then suggests that (gains from) globalization becomes politically more contentious in its more advanced stages. Yet economics alone cannot offer a rigorous justification of whether and how to compensate those actors that suffer losses from moves to freer trade. Instead, we are in the realm of normative perspectives or theories that would guide governments on what policies they should adopt in this context under some conception of right or wrong. ${ }^{28}$ To take one targeted example, a Rawlsian distributive justice claim would call for compensation to those adversely affected by trade liberalization, especially if they are in the most disadvantaged sections of society (such as low-paid factory workers). ${ }^{29}$ Yet leaving aside those theories, self-interest of a sort may also justify compensation. From a classic political economy perspective, theoretically one can position compensation or mitigation techniques as a logical counter to intense lobbying by interest groups opposed to greater liberalization. The legal strictures of the GATT regime are in no way a constraint on such domestic policies of redistribution. And in fact, some countries, like the USA, have long created positive adjustment programs targeted at trade-displaced workers. ${ }^{30}$ In Europe also, these sort of policies were introduced after the Second World War. With the creation of a common market for coal and steel in the European Coal and Steel Community, workers were able to benefit from 'readaptation aid'. Aid, including extensive retraining programs, was granted to workers in the coal and steel sectors whose jobs were threatened by industrial restructuring. The European Social Fund, created in the early 1960s, was the principal weapon in combating unemployment. ${ }^{31}$ These though appear to constitute something

Dani Rodrik, 'Populism and the Economics of Globalization', 1 Journal of International Business Policy (2018), at 4.

27 Mary Burfisher, Frederic Lambert, and Troy Matheson, 'NAFTA to USMCA: What Is Gained?' (IMF Working Paper No. WP/19/73, March 2019).

28 Oisin Shuttle, Distributive Justice and $W$ orld Trade Law (Cambridge: Cambridge University Press, 2018) 37-48 (outlining different theories).

29 Michael Trebilcock, Dealing with Losers: The Political Economy of Policy Transitions (Oxford: Oxford University Press, 2014) 68.

30 Trebilcock, above n 30, at 78.

31 European Community Information Service, Social Policy in the European Coal and Steel Community 195365, http://aei.pitt.edu/34501/1/A670.pdf (visited 14 May 2019). 
of a minority as many states have seemingly banked on natural amelioration of the shortterm adjustments costs as workers transitioned over the long term to more competitive sectors of the economy. Strikingly, key international organizations have now taken up the distributional problem calling for greater targeted domestic policies to mitigate trade adjustment costs. ${ }^{32}$ To be sure, there are difficult (perhaps even intractable) design issues in constructing a specific adjustment mechanism to counter the negative effects (on workers) of trade liberalization, not least sticky issues of how to identify with some certainty those losers. Yet here too, the public choice assumption seems to be that the concerns of workers (labor) are less likely to have the political traction of importcompeting industry (capital) as an obstacle to free trade, sharpened by the decline in organized labor across the developed world (thereby limiting possibilities of collective bargaining). ${ }^{33}$

It is important here to be mindful of the heterogeneity of the harm occasioned by trade-induced dislocation and how it can slowly but inevitably acculturate over time into political demands. Generally speaking, adjustment of this sort has asymmetric effects based on age with younger workers experiencing relatively smaller costs vis-àvis older workers. Aside from direct economic costs (including income/consumption foregone due to unemployment and adjustment costs of retraining to enable transition), there are hidden psychological costs of unemployment that must be borne in mind. A protracted period of unemployment can trigger physical and mental illness, family dissolution, and anti-social behavior (including through alcohol and drug dependence). ${ }^{34}$ In the absence of targeted or general support through a functioning social safety net, the newly unemployed may seek employment at lower wage levels and in occupations of lower skill and labor productivity. ${ }^{35}$ This phenomenon then bleeds into growing patterns of income inequality across much of the developed world and political concerns of the social costs associated with economic globalization.

\section{INTERVENING: BOUNDED RATIONALITY}

Since the 1970s, the assumptions underpinning the rational choice paradigm have been thoroughly challenged by psychological and economic experimental research. These findings have revolutionized huge parts of economics as well as the economic analysis of law. Economic tools like game theory or contract theory relevant to international trade law have been transformed by behavioral economics, ${ }^{36}$ adding new insights in several issue areas of (economic) law and policy. But those insights remain in their infancy

32 International Monetary Fund, World Bank, World Trade Organization, Making Trade an Engine of Growth for All The Case for Trade and for Policies to Facilitate Adjustment (2017), available at: https: / www.wto.org/ english/news_e/news17_e/wto_imf_report_07042017.pdf (visited 9 September 2019).

33 See Dani Rodrik, above n 26 , at 7.

34 On the adverse impacts of unemployment on life satisfaction, see Rainer Winkelmann, 'Unemployment and Happiness', 94 IZA W orld of Labor 1-10 (2014).

35 See Trebilcock, above n 30, at 67.

36 For game theory, see Colin Camerer, Behavioral Game Theory. Experiments in Strategic Interaction (Princeton: Princeton University Press, 2003). For contract theory, see Botond Koszegi, 'Behavioral Contract Theory', 52 Journal of Economic Literature 1075 (2014). 
in political economy, ${ }^{37}$ including in the explanation of trade policy. ${ }^{38}$ There, research remains mainly focused on loss aversion. ${ }^{39}$

Experiments are used to observing people's social preferences and cognition under controlled conditions. ${ }^{40}$ Many experiments show deviations from thin, cognitive rationality by demonstrating that individuals' preferences often do not comply with the formal requirements of rationality. Furthermore, the assumption of thick, motivational rationality (especially purely self-regarding preferences) is challenged by the role that factors such as fairness, envy, and altruism play in people's behavior. This enriched model strives to understand how people really behave.

As a start point, a careful consideration of the relevant unit of analysis is in order when it comes to political economy. ${ }^{41}$ The relevant actors here are government (or politicians) as well as citizens and business (and their lobby groups). Generally, when applying behavioral economics to international relations ${ }^{42}$ or international law, ${ }^{43}$ the focus has been on state behavior as a unitary actor or on government leaders as individuals. Once we break up the 'black box', the insights from behavioral economics can be applied more easily. Here, four combinations are in principle possible. Bounded rational voters may encounter bounded rational politicians (and/or administrators), ${ }^{44}$ bounded rational voters may face rational politicians (who may exploit bounded rationality of the voters), rational voters may be confronted with bounded rational politicians, and rational voters may combine with rational politicians. Of course, the latter combination is the basis for classical public choice theory, as well as the political economy story of trade and trade agreements. We will focus instead on bounded rational voters, in combination with rational or bounded rational politicians, and seek to identify the heuristics and biases which may impede the fulfillment of ideal preferences as postulated in classic public choice theory.

Political psychologists have shown that citizens' judgment and choices are deeply affected by the limitations on their ability to acquire, recall, and process information

37 Jan Schnellenbach and Christian Schubert, 'Behavioral Political Economy: A Survey', 40 European Journal of Political Economy 395 (2015); Eyal Zamir and Doron Teichman, Behavioral Law and Economics (Oxford: Oxford University Press 2018) 393-409.

38 For a non-rationalist account of investment policy using 'constructivist political economy' and focusing on uncertainty, see Jonathan Bonnitcha, Investment Wars: Contestation and Confusion in Debate about Investment Liberalization, in this special issue.

39 Patricia Tovar, 'The Effects of Loss Aversion on Trade Policy: Theory and Evidence', 78 Journal of International Economics 154 (2009); Caroline Freund and Çaglar Özden, 'Trade Policy and Loss Aversion', 98 American Economic Review 1675 (2008).

40 They may be conducted in the field or in laboratory settings and may assess individual or group behavior.

41 Cf. Anne van Aaken, 'Behavioral International Law and Economics', 55 Harvard International Law Journal 421 (2014); Tomer Broude, 'Behavioral International Law', 163 University of Pennsylvania Law Review 1099 (2015).

42 Emilie M. Hafner-Burton and others, 'The Behavioral Revolution and International Relations', vol. 71, supplement S1 International Organization S1 (2017); Rose McDermott, Political Psychology in International Relations (Ann Arbor: Michigan University Press, 2004); James Davis (ed.), Psychology, Strategy and Conflict (London: Routledge, 2013).

43 Cf van Aaken, above n 41.

44 Cf. for a behaviorally enriched public choice theory, Jeffrey J. Rachlinski and Cynthia R. Farina, 'Cognitive Psychology and Optimal Government Design', 87 Cornell Law Review 549 (2002). 
and are mostly determined by implicit attitudes and automatic reactions that they are not necessarily aware of, as well as by the interplay of affect and cognition. ${ }^{45}$ While we draw on this general research, our focus is especially on those biases that offer the greatest potential to explain the current outbreak of protectionist tendencies in different parts of the globe. Several biases and heuristics are particularly relevant to understanding the political economy of trade through a behavioral lens. We focus on loss aversion (including the endowment effect), framing, the availability bias, so-called hawkish biases, and fairness.

\section{A. Prospect theory: loss aversion, reference points, endowment, and the status quo}

While rational choice theory assumes that people perceive outcomes in absolute terms (expected utility), prospect theory posits that people ordinarily perceive outcomes as either gains or losses, rather than as final states. ${ }^{46}$ Gains and losses are defined in relation to some reference point, usually (but not invariably) the status quo or an entitlement. A loss counts more than a gain (loss aversion). Empirical estimates of loss aversion are typically close to 2 , meaning that the disutility of giving something up is twice as large as the utility of acquiring it. What counts as a loss or as a gain depends on the reference point. Mostly, the status quo is taken as the reference point and changes from this point are viewed either as losses or gains. But it can also be influenced by expectations which can in turn be influenced by envisaged prospects or entitlements. The reference point is also influenced by status of other people. ${ }^{47}$ In the domain of gains, people exhibit risk aversion, whereas they are risk seeking in the domain of losses.

\section{B. Framing}

Closely connected to prospect theory but with further implications is the framing of decisions. Framing effects similarly violate a basic tenet of rational choice theory that individual preferences do not change from alternative ways of eliciting the same preference. A framing effect exists 'when different ways of describing the same choice problem change the choices that people make, even though the underlying information and choice options remain essentially the same. ${ }^{48}$ Many experiments explore those effects. ${ }^{49}$ The mechanism at work is that frames influence beliefs, and beliefs in turn

45 Generally, see Leonie Huddy, David O. Sears, and Jack S. Levy (eds), Oxford Handbook of Political Psychology, 2nd ed. (Oxford: Oxford University Press, 2013).

46 Daniel Kahneman and Amos Tversky, 'Prospect Theory: An Analysis of Decisions under Risk', 47 Econometrica 312 (1979); Daniel Kahneman and Amos Tversky, 'Advances in Prospect Theory: Cumulative representation of uncertainty', 5 Journal of Risk and Uncertainty 297 (1992); Jack S. Levy, 'Prospect Theory and International Relations: Theoretical Applications and Analytical Problems', 13 Political Psychology 283 (1992).

47 See Zamir and Teichman, above n 37, at 45f.

48 R. Cookson, 'Framing Effects in Public Goods Experiments', 3 Experimental Economics 55 (2000), at 55; Tore Ellingsen and others, 'Social Framing Effects: Preferences or Beliefs?', 76 Games and Economic Behavior 117 (2012), at 118 for different theories about framing.

See Ellingsen and others, above $\mathrm{n} 48$. 
influence behavior. ${ }^{50}$ Specific examples abound from framing ultimatum games ${ }^{51}$ as a product of resource scarcity generates higher offers and fewer rejections; ${ }^{52}$ framing negotiations as taking place in an international rather than a business context triggers more cooperative behavior; ${ }^{53}$ and framing a prisoner's dilemma as a trust game can increase cooperation (and vice versa). ${ }^{54}$ It has also been explored in the political economy context, including studies of voting and public opinion, campaigns, policymaking, and foreign-policy and a variety of other topics. ${ }^{55}$ The category of issue framing is especially important for our purposes. Issue frames focus on qualitatively different yet potentially relevant considerations. Issue framing effects refer to situations whereby, emphasizing a subset of potentially relevant considerations, a speaker leads individuals to focus on these considerations when constructing their opinions. In particular, describing a trade policy issue as a security issue may cause people to base their opinions on security threats instead of the trade implications of protectionist policies. ${ }^{56}$

\section{Availability bias}

Another common cognitive blinder is the availability bias, which leads decision-makers to rely on examples and evidence that come immediately to mind. It is connected to the assessment of probabilities. Often, the estimated likelihood of an event and the frequency of its occurrence is based on ease of recalling similar events or occurrences. ${ }^{57}$ This bias results because people's attention is more readily drawn to emotionally salient and easily recalled events, even ahead of objectively more likely and impactful events. Media play an enormous role in shaping this bias, including social media such as Twitter.

\section{Hawkish biases}

Many biases uncovered by psychological research favor hawkish decisions in conflict situations, including those described by prospect theory. The term 'hawkish' denotes a propensity for suspicion, hostility, and aggression, and for less cooperation and trust for the resolution of the conflict. Actors who are susceptible to hawkish biases are not

50 Martin Dufwenberg, Simon Gächter, and Heike Hennig-Schmidt, 'The Framing of Games and the Psychology of Play', 73 Games and Economic Behavior 459 (2011).

51 In this experiment, the proposer makes an offer of how to share a fixed amount, which the recipient can accept or reject. If the recipient rejects, both get nothing. In a homo economicus model, a proposer would offer the smallest monetary unit, and the recipient would accept it. Yet experiments do not obtain this result.

52 Colin F. Camerer, Behavioral Game Theory: Experiments in Strategic Interaction(Princeton: Princeton University Press, 2003) 75.

53 Richard J. Eiser and Kum Kum Bhavnani, 'The Effect of Situational Meaning on the Behavior of Subjects in the Prisoner's Dilemma Game', 4 European Journal of Social Psychology 93 (1974).

54 Generally, see Brian Skyrms, The Stag Hunt and the Evolution of Social Structure (Cambridge: Cambridge University Press, 2004); experimentally, see Terence Burnham, Kevin McCabe, and Vernon L. Smith, 'Friend-or-Foe Intentionality Priming in an Extensive Form Trust Game' 43 (1) Journal of Economic Behavior \& Organization 57 (2000).

55 James N. Druckmann, 'Political Preference Formation: Competition, Deliberation and the (Ir)relevance of Framing Effects', 98 American Political Science Review 671 (2004).

56 For a similar example based on experiments, see ibid. at 672.

57 Amos Tversky and Daniel Kahneman, 'Availability: A Heuristic for Judging Frequency and Probability', 5 Cognitive Psychology 207 (1973). 
only more likely to see threats as direr than an objective observer would perceive,but also likely to act in a way that will produce unnecessary conflict. Many biases play a role in this distortion, but we will deal only with those we deem especially relevant in the current trade context. Overconfidence (that is, the tendency of actors' subjective confidence in their judgments to be reliably greater than the objective accuracy of those judgments), as well as the fundamental attribution error ${ }^{58}$ and the 'illusion of control' (which is an exaggerated perception of the extent to which outcomes depend on one's actions), tends to produce more hawkish decisions in international conflict situations. Actors subject to hawkish biases are mostly also overconfident in being able to 'win' the conflict and they are in turn risk-seeking. ${ }^{59}$

\section{E. Fairness and equity}

Experiments on social preferences - motivational factors - use game theory including the ultimatum game ${ }^{60}$ and the dictator game, ${ }^{61}$ which have been extensively deployed in different forms. Experimental research has shown that individuals are also motivated by other-regarding/altruistic and social preferences and have proven the purely selfregarding preference assumption of rational choice theory is flawed. The experiments thus suggest that rationalist theories may be faulted for neglecting, inter alia, altruism, spitefulness, and preferences for equality and the perceived intentions of the other players. ${ }^{62}$ Indeed, people can be altruistic but they can also be spiteful. Behavioral insights in experimental games show punishment by other players takes place, ${ }^{63}$ albeit

58 The fundamental attribution error denotes the tendency to attribute other people's behavior to their personal attitudes and motivations, rather than to environmental influences and constraints; see for details Zamir and Teichman, above n 37, at Chapter 2.

59 Daniel Kahneman and Jonathan Renshon, 'Hawkish Biases'in Trevor Thrall and Jane K. Cramer (eds), American Foreign Policy and the Threat of Fear: Threat Inflation Since 9/11 (London: Routledge, 2009).

60 The experiments started with the so-called Ultimatum Game. See Güth, Schmittberger, and Schwarze, 'An Experimental Analysis of Ultimatum Bargaining', 3 Journal of Economic Behavior and Organization 367 (1982). The proposer makes an offer of how to share a given amount (usually money) and the recipient can accept or reject the offer. In case of acceptance, the offered division is implemented; in case the recipient rejects, both get nothing. If the recipient is motivated solely by monetary payoffs, he or she will accept every offer. Therefore, the proposer will only offer the smallest money unit: this is expected by the homo economicus hypothesis but not found in the experiments. This is attributed to fairness considerations which are, when left unfulfilled, punished even if costly to the punisher.

61 The 'dictator' determines how to split an endowment (such as a cash prize) between himself and the second player. The second player simply receives the remainder of the endowment left by the dictator. Most people all over the world share the endowment, although there is no sanction for not doing so. This contradicts the rational choice assumption. For a meta-analysis, see Christoph Engel, 'Dictator Games: A Meta Study', 14 Experimental Economics 583 (2011). For details, see Ernst Fehr and Klaus M. Schmidt, 'The Economics of Fairness, Reciprocity and Altruism-Experimental Evidence and New Theories' in S. Kolm and J. Mercier Ythier (eds), Handbook of the Economics of Giving, Altruism and Reciprocity Vol 1 (Amsterdam: Elsevier, 2006), 615-691.

62 Armin Falk, Ernst Fehr, and Urs Fischbacher, 'Testing theories of fairness-Intentions matter', 62 Games and Economic Behavior 287 (2008); Ernst Fehr and Klaus M. Schmidt, 'The Economics of Fairness, Reciprocity and Altruism-Experimental Evidence and New Theories', in Serge Kolm and Jean Mercier Ythier (eds), Handbook of the Economics of Giving, Altruism and Reciprocity Vol I (Amsterdam: Elsevier, 2006).

63 For a discussion of the motives to punish, see Armin Falk, Ernst Fehr, and Urs Fischbacher, 'Driving Forces behind Informal Sanctions', 73 Econometrica 2017 (2005). 
costly to themselves, if there is a perceived violation of a norm (be it a fairness norm or a legal norm).

Equity theory has explored the substantive fairness concerns of people. It focuses on determining whether the distribution of resources is fair to both relational partners. Individuals who perceive themselves as either under-rewarded or over-rewarded will experience distress, and this distress leads to efforts to restore equity within the relationship such as by decreasing their contributions or by quitting the relationship. Furthermore, psychological studies reveal that people care about fairness even when it is at odds with or unrelated to their self-interest. ${ }^{64}$ Yet, here another biases kicks in - the confirmation bias. It is the tendency to search for, interpret, favor, and recall information in a way that confirms one's preexisting beliefs or hypotheses. ${ }^{65}$ People also tend to interpret facts or norms in a self-serving manner, that is, they tend to take personal responsibility for desirable outcomes yet externalize responsibility for undesirable outcomes. $^{66}$

\section{A BEHAVIORAL POLITICAL ECONOMY APPROACH TO PROTECTIONISM}

As we have noted, the dominant approach to the study of international political economy assumes that the policy preferences of individuals and groups reflect economic self-interest (material preferences). Recent research has called this assumption into question by suggesting that voters do not have economically self-interested preferences about trade policy given that the economic consequences of protectionism and trade wars can be severe and economically costly for those who support it. ${ }^{67}$ One potential explanation is simple economic ignorance, and this can indeed be shown: most voters do not understand the economic consequences of protectionism. ${ }^{68}$ But apart from ignorance, many other heuristics and biases uncovered by behavioral psychology are also at play. We now turn to explore the manner in which various behavioral insights,

64 J. Stacy Adams, 'Inequality in Social Exchange', 2 Advances in Experimental Social Psychology 267 (1965); Zamir and Teichman, above $\mathrm{n} 37$, at 102-104.

65 Raymond S. Nickerson, 'Confirmation Bias: A Ubiquitous Phenomenon in Many Guises', 2 Review of General Psychology 175 (1998).

66 James Shepperd, Wendi Malone, and Kate Sweeny, 'Exploring Causes of the Self-serving Bias', 2 Social and Personality Psychology Compass 895 (2008).

67 Pablo D. Fajgelbaum, Pinelopi K. Goldberg, Patrick J. Kennedy, and Amit K. Khandelwal, The Return to Protectionism, Working Paper, available at http://www.econ.ucla.edu/pfajgelbaum/RTP.pdf (visited 23 July 2019); this paper analyzes the 2018 trade war on the US economy. Imports from targeted countries declined $31.5 \%$ within products, while targeted US exports fell by $11.0 \%$. They find complete pass-through of US tariffs to variety-level import prices. Annual consumer and producer losses from higher costs of imports were $\$ 68.8$ billion ( $0.37 \%$ of GDP). After accounting for higher tariff revenue and gains to domestic producers from higher prices, the aggregate welfare loss was still $\$ 7.8$ billion ( $0.04 \%$ of GDP). Whereas US tariffs favored sectors located in politically competitive counties, retaliatory tariffs offset the benefits to these counties. They find that tradeable-sector workers in heavily Republican counties were the most negatively affected by the trade war.

68 Sungmin Rho and Michael Tomz, 'Why Don't Trade Preferences Reflect Economic Self-Interest?', 71 International Organization S85 (2017). 
operating cumulatively, have explanatory potential for the contemporary outbreak of protectionism.

\section{A. Inequality and hegemonic status: loss aversion}

Prospect theory and loss aversion have been best researched hitherto in the political economy of trade. It is puzzling for trade economists, assuming material preferences and their rational pursuit, to explain the deviation from their preferred model of utility gains. But some insights from behavioral psychology offer a contrasting account that challenges the centrality of key economic assumptions.

Consider as a start-point that utility when it comes to free trade is largely one that flows from increased consumption possibilities. Yet psychological research has shown that employment has value for people over and above the purchasing power provided by the income people earn. ${ }^{69}$ The research plainly shows that people's happiness and wellbeing is heavily influenced by their work satisfaction but much less by their income. As Kemp points out, 'people derive benefits from their work which go beyond income or the consumption obtainable from this income, and which are not easily compensated for by income changes and adjustments. ${ }^{70}$ Trade-induced job dislocation (loss) of the sort described in Part II or even the perceived likely prospect of unemployment can therefore generate significant psychological harm that, critically, may not simply disappear when people re-enter the workforce. This in turn limits the political traction to boundedly rational voters of empirical and aggregate claims made by economists such that reductions in employment in manufacturing from the 'China shock' have been simply off-set by gains in employment in the services sector in the USA. ${ }^{71}$ Voters tend to recall the loss, and to discount the off-setting gains. Since losses loom larger than gains, this may indicate that a pure off-setting is insufficient - suggesting that gains from trade would need to be twice as large as losses to convince loss averse citizens of the gains of freer trade.

Relatedly, Patricia Tovar has used individual loss aversion to explain why a disproportionate share of protection goes to declining industries and why trade policy has an antitrade bias. ${ }^{72}$ She shows that if individual preferences exhibit sufficient loss aversion, higher protection will be given to sectors in which profitability is declining (at odds with the usual political economy notion that bigger and expanding industries would be in a better position to finance lobbying and therefore receive governmental support). She also shows that if the coefficient of loss aversion is large enough, there will be an antitrade bias in trade policy. Furthermore, increasing anxiety that foreign commerce would harm people in the future (including leading to unemployment), even if it had not done 72 Tovar, above n 39.

\footnotetext{
Bernard Hoekman and Douglas Nelson, 'Reflecting on Populism and the Economics of Globalization', 1
Journal of International Business Policy 34 (2018), at 36 . To be sure, China is only part of the story on the
loss of manufacturing jobs in the rich world. For an account on waves of outsourcing, see Richard Baldwin,
The Globotics Upheaval: Globalization, Robotics, and the Future of $W$ ork (Oxford: Oxford University Press
2019). Bernard Hoekman and Douglas Nelson, 'Reflecting on Populism and the Economics of Globalization', 1
Journal of International Business Policy 34 (2018), at 36 . To be sure, China is only part of the story on the
loss of manufacturing jobs in the rich world. For an account on waves of outsourcing, see Richard Baldwin,
The Globotics Upheaval: Globalization, Robotics, and the Future of $W$ ork (Oxford: Oxford University Press
2019). Bernard Hoekman and Douglas Nelson, 'Reflecting on Populism and the Economics of Globalization', 1
Journal of International Business Policy 34 (2018), at 36 . To be sure, China is only part of the story on the
loss of manufacturing jobs in the rich world. For an account on waves of outsourcing, see Richard Baldwin,
The Globotics Upheaval: Globalization, Robotics, and the Future of $W$ ork (Oxford: Oxford University Press
2019). Bernard Hoekman and Douglas Nelson, 'Reflecting on Populism and the Economics of Globalization', 1
Journal of International Business Policy 34 (2018), at 36 . To be sure, China is only part of the story on the
loss of manufacturing jobs in the rich world. For an account on waves of outsourcing, see Richard Baldwin,
The Globotics Upheaval: Globalization, Robotics, and the Future of $W$ ork (Oxford: Oxford University Press
2019).

Simon Kemp, 'Psychology and Opposition to Free Trade', 6 World Trade Review 25 (2007), at 28. Ibid, at 29.
} 
so thus far, has been found to contribute to mounting opposition to trade among the American public. ${ }^{73}$ This seems to be explicable by the status quo bias of which every deviation is seen as a loss and leads to risk-seeking behavior-given that protectionism and ensuing trade wars may lead to material losses for exactly those people who favor protectionist policies. ${ }^{74}$ Research also suggests that people who are influenced by the status quo bias are likely to oppose import liberalization even after controlling for each individual's various characteristics, suggesting that neither income compensation nor insurance schemes are sufficient for expanding support for free trade. ${ }^{75}$ Narratives around trade can alone create expectations, and when a trade treaty is concluded, the government would usually aggressively promote talk about gains for all from the treaty. This, for example, happened with the conclusion of NAFTA. ${ }^{76}$ Since expectations can also create reference points, if the gains from trade are not realized for all, this in turn may be perceived as a loss. Of course, there are always losers from trade but the point here is that if gains are not reaped, this alone is perceived as a loss, even if the objective status quo remains the same.

It is important to be mindful of the impact of patterns of rising inequality within the rich world (including the USA) after a relative egalitarian distribution until $1980 .{ }^{77}$ Using an endowment effect or an entitlement and framing any deviation as a loss can provoke loss aversion. The expected gain from globalization for all citizens may act as a reference point, and if that gain remains unrealized, this would be perceived as a loss by the middle class of the developed world. If voters feel that they are entitled to a certain economic status or they fear a deviation from the current status quo of their economic or social position, that may lead to loss aversion. Rising inequality amounts to a perceived relative loss within those countries (with the exception of the very rich). The anxiety of losing against the status of other citizens (which may act as a reference point) not only in absolute but also in relative terms seems crucial.

Importantly, the explanatory value of loss aversion goes beyond the specific impact of harm or perceived harm to individual voters. We can also position the status of other countries as a reference point in tracing a different type of loss aversion. Indeed, one experiment has shown that a shift in that sort of reference point can lead to reversals of preferences in the evaluation of political and economic options. While subjects would usually support candidates with less risky economic policies when their country was expected to do better than other countries, that changes once it was their country that was expected to do worse as they would then switch to candidates who propose riskier

73 Edward D Mansfield, Diana C. Mutz, and Devon Brackbill, 'Effects of the Great Recession on American Attitudes Toward Trade', 49 British Journal of Political Science 37 (2016).

74 See above $\mathrm{n} 67$.

75 Eiichi Tomiura and others, 'Individual Characteristics, Behavioral Biases, and Trade Policy Preferences: Evidence from a Survey in Japan', 24 Review of International Economics 1081(2016).

76 President Clinton at the signing ceremony said: 'NAFTA will create 200.000 jobs in this country by 1995 alone', see Youtube Video, https://www.youtube.com/watch?v=b3ooMrgXido, at minute 2.06. 'will promote more growth, more equality, better conservation of the environment', at minute 1.27.

77 Acundo Alvaredo and others, 'The Elephant Curve of Global Inequality and Growth', 108 AEA Papers and Proceedings 103 (2018) and Christoph Lakner and Branko Milanovic, 'Global Income Distribution: From the Fall of the Berlin Wall to the Great Recession', 30 The World Bank Economic Review 203 (2016). 
policy options. ${ }^{78}$ This seems to have clear resonance in the type of discourse on trade seen recently in the USA. The USA has clearly been a global economic superpower for a long period since the end of the Second World War. On some measures, however, China is estimated to overtake the USA somewhere between 2030 and $2040 .{ }^{79}$ President Trump repeatedly used 'Make America Great Again' as a campaign slogan in the 2016 Presidential election which directly invokes loss aversion (great again, implying that it has lost out after being great). ${ }^{80}$ Consider how these repetitive rhetorical formulations on the relative status of the USA as a country magnify and build upon localized anxieties felt by individual voters.

The perceived loss due to the rising inequality within countries combined with the absolute rise of equality between countries can trigger a double loss frame (particularly for the middle-class citizens of the rich world). This perceived individual loss and national loss can profoundly shape anti-trade preferences.

\section{B. Framing the discourse on trade policy: geo-economics and security}

Research on the framing of trade policy preferences suggests that material conditions associated with income and price effects are crucial, both in shaping trade preferences and in affecting the malleability of attitudes to issue framing. The results show susceptibility to political framing in policy debates. ${ }^{81}$ Furthermore, the impact of issue framing on individuals' stated attitudes toward international trade has been found to be strong, especially among less educated people. ${ }^{82}$ Whereas negative framing evokes more protectionist sentiments, positive framing has no effect, unless it is underpinned by economists' expert views. ${ }^{83}$

Recently, especially under the Trump administration, trade has been prominently framed as a security issue and positioned in conflictual instead of cooperative terms. This reflects a sharp break from past understandings of the role of economic interdependence in decreasing conflict between states. Under the leadership of the USA, the original framers of the GATT were motivated by the Kantian belief that economic isolation and state discrimination against private foreign actors engenders adverse political consequences resulting in political instability and irritation. By sharp contrast, a new

78 George A. Quattrone and Amos Tversky, 'Contrasting Rational and Psychological Analyses of Political Choice', 82 American Political Science Review 719 (1988).

79 IMF Country Focus, IMF Country Focus, China's Economic Outlook in Six Charts, July 26, 2018, https:// www.imf.org/en/News/Articles/2018/07/25/na072618-chinas-economic-outlook-in-six-charts (last visited 25 April, 2019). See also Niall Ferguson and Xiang Xu, 'Make Chimerica Great Again', (Hoover Institute Working Paper 18105, 3 May 2018).

80 Financial Post, China, will overtake the US economy in less than 15 years, says HSBC, challenging Trump's claim, September 25, 2018, https://business.financialpost.com/news/economy/china-will-overtake-theu-s-in-less-than-15-years-hsbc-says (visited 25 April 25, 2019).

81 Martin Ardanaz, Victoria Murillo, and Pablo Pinto, 'Sensitivity to Issue Framing on Trade Policy Preferences: Evidence from a Survey Experiment' 67 International Organization 411 (2013).

82 Anna Maria Mayda and Dani Rodrik, 'Why Are Some People (and Countries) More Protectionist than Others?', 49 European Economic Review 1393 (2005) (finding that pro-trade preferences are significantly and robustly correlated with an individual's level of human capital).

83 Michael J. Hiscox, 'Through a Glass and Darkly: Attitudes Toward International Trade and the Curious Effects of Issue Framing', 60 International Organization 755 (2006). 
conflictual frame has been deployed in the USA which suggests trade now threatens national security not only in relation to China but also for aluminum and steel imports from a range of long-standing American allies like Australia, Canada, and member states of NATO. Strikingly, the Trump Administration has even threatened to impose tariffs against car imports from the European Union suggesting these threaten national security. There is no legal basis for the claim made by the USA to justify the imposition of these tariffs as has been confirmed given recent WTO Panel rulings on the scope of state autonomy to invoke security exceptions under the law of the WTO. ${ }^{84}$ But the legal position-hobbled in any event by the time delay in WTO dispute settlement coupled with the prospective nature of remedies in the $\mathrm{WTO}^{85}$ - is no counter to the turbulent manner in which the new security claim distorts trade policy dialogue and preference. Security is an especially forceful frame for shaping preferences as it can provoke immediate loss aversion. The framing of a 'war' and China as an 'enemy' can recast popular perceptions, as polls on public support for the government when at war tend to show people exhibit what they view as patriotism. ${ }^{86}$ Hawkish biases are typical in security and conflict situations, and, if in a loss frame, individuals tend to make more risky choices. Actors who are susceptible to these hawkish biases are then likely to act in a way that will produce unnecessary conflict such as a trade war. ${ }^{87}$

These biases are likely to be magnified when we consider the impact, once again, of the relative decline of the USA as a political and economic power. Some indeed argue that hegemonic stability theory is at play in what they have described as an 'emerging geoeconomic world order. ${ }^{88}$ Under this claim, a hegemon like the USA will support economic cooperation only where it does not fear the economic growth of strategic rivals. But when the relative size of the economies of the hegemon and its strategic rival converge to a sufficient degree, the hegemon's sense of security diminishes and preference for free trade will weaken considerably. It is certainly true that the strategic choices of other states haves shaped and deepened the framing of trade policy in the USA. In the run-up to the 2016 US presidential election, China publicly released its 'Made in China 2025 ' blueprint of upgrading manufacturing capabilities of Chinese industries. ${ }^{89}$ From a Chinese perspective, that goal seems logical given China's development trajectory and the importance of transitioning from labor-intensive industries in a way that avoids the so-called 'middle income trap'. But that policy has dominated US trade policy discourse internally in a way that again portrays China as an existential threat to US technological

Russia-Measures Concerning Traffic in Transit, Report of the Panel (WT/DS512/R), 5 April 2019), para. 7.82 (finding that action must be 'objectively' found to fall within the security exception in GATT Art. XXI).

85 Joseph H.H. Weiler, 'Editorial: Black Lies, White Lies and Some Uncomfortable Truths in and of the International Trading System', 29 (2) European Journal of International Law 339 (2018), at 342.

86 The 'rally around the flag' phenomenon is well researched in political science; see William D. Baker and John R. Oneal, 'Patriotism or Opinion Leadership?: The Nature and Origins of the 'Rally “Round the Flag” Effect', 45 (5) The Journal of Conflict Resolution 661 (2001). We would like to thank one reviewer for this thought.

87 See Kahneman and Renshon, above n 59.

88 See especially in this special issue, Anthea Roberts, Henrique Choer Moraes, and Victor Ferguson, 'Toward a Geoeconomic World Order'.

89 We are agnostic about whether China has chosen that time on purpose. Our interest is only on its impact on the security frame deployed by the USA vis-à-vis China. 
leadership. ${ }^{90}$ Beyond general rhetoric, the specific intermingling of trade and security concerns in US political policy targeted, explicitly or implicity, against China has grown exponentially in the last few years from US export controls on emerging technologies (November 2018) ${ }^{91}$ to submission of Huawei on an entity list banning US companies selling to Huawei without government approval (May 2019). ${ }^{92}$

At this stage, the reader might recall our focus on bounded rational voters in combination with rational or boundedly rational politicians. To a very large part, our analysis so far-especially on loss aversion-has focused mainly on constraints to rationality of individuals that can explain their voting support for protectionist outcomes. On the point of the security frame, however, there is a live question of the rationality of the American political actor(s) responsible for the imposition of tariffs on security grounds. Of course, it could simply be that the Trump Administration is strategically using security to manipulate a boundedly rational voting population for their own political purposes. And indeed, the domestic legal mechanisms used to deploy the security tariffs (under section 232 of the US Trade Expansion Act of 1962) leave the US Executive relatively unconstrained from legislative oversight, naturally suggesting some sort of political expediency in their active deployment. Nonetheless, these hostile beliefs have a longer genesis than the last US presidential election. Donald Trump, in particular, has had a historical view of trade as a zero-sum competition for resources between states that predates his election to the presidency. ${ }^{93}$ Relatedly, US Trade Representative Robert Lightizer's has long supported aggressive unilateralism in trade policy and positively disdains multilateral political cooperation of the sort embodied in the WTO. ${ }^{94}$ Not surprisingly then, the Trump administration frames trade negotiations as business negotiations and as a zero-sum game with security aspects (thus further invoking loss aversion). ${ }^{95}$ This elicits less cooperation than framing it as an international negotiation. ${ }^{96}$ Although we focus on bounded rationality of voters and do not take a view on the rationality of the Trump administration, it is plausible to assume that President Trump seems to be (over)confident that he can 'win' the trade war invoking

90 Lorand Laskai, 'Why Does Everyone Hate Made in China 2025?', Council on Foreign Relations, 28 March 2018, https://www.cfr.org/blog/why-does-everyone-hate-made-china- 2025 (visited 2 May 2019).

91 Export Control Reform Act (2018), National Defence Authorization Act for Fiscal Year 2019, Public Law No. 115-232.

92 Department of Commerce (Bureau of Industry and Security), 'Addition of Certain Entities to the Entity List and Revision of Entries on the Entity List', 15 CFR Part 744, Federal Register, Vol 84, No. 162, 43,493 (21 August 2019).

93 Binyamin Appelbaum, 'On Trade, Donald Trump Breaks with 200 Years of Economic Globalization', New York Times, 10 March 2016, https://www.nytimes.com/2016/03/11/us/politics/-trade-donaldtrump-breaks-200-years-economic-orthodoxy-mercantilism.html?searchResultPosition=4 (visited 2 May 2019) ('Mr Trump's mercantilism is among his oldest and steadiest public positions. Since at least the 1980s, he has described trade as a zero-sum game in which countries lose by paying for imports') Quinn Slobodian, 'You Live in Robert Lighthizer's World Now'(6 August 2018) Foreign Policy, https://foreignpolicy.com/2018/08/06/you-live-in-robert-lighthizers-world-now-trump-trade/ (visited 13 September 2018).

95 See e.g. Trump Tweet "The EU has taken advantage of the U.S. on trade for many years. It will soon stop!“09.04.2019, https://twitter.com/realDonaldTrump/status/1115578769518018560 
an illusion of control. He surely conveys a fundamental attribution error to the public, basically attributing the fault for the US trade deficit on the unfairness of its trading partners and the trade agreements concluded with them, insinuating that they are taking advantage of the USA, ${ }^{97}$ including technological advantage (especially China).

\section{China and trade: availability bias}

China and notions of unfair trade featured prominently on the campaign trial in the USA in the 2016 US presidential election. Yet, the public association of China as a trade threat has a longer (though still relatively recent) lineage especially around Chinese accession to the WTO in 2001, and critically, it has gathered powerful momentum in media coverage over recent years. Autor, Dorn, and Hanson have documented the large, persistent, and highly localized labor-market disruption in the USA from patterns of international trade flows from China over the period 1990 to $2007 .{ }^{98}$ But the tight media attention on issues surrounding trade with China has extended beyond this 'China shock' of trade displacement in the USA. The news media routinely features reporting on issues such as the 'Made in China 2025' industrial strategy, select but high-profile Chinese economic interventions (such as purchase of the iconic Waldorf Astoria hotel in 2018), ${ }^{99}$ and most recently, the spread of China's ongoing 'Belt and Road' initiative.

In the analysis below, we empirically explore how salient and available topics like trade, China, and/or tariffs are to the American public. We do so by focusing on possible mechanisms that can contribute to such salience, bearing in mind the powerful impact of availability bias in shaping voter perceptions on trade. We are particularly interested in presidential discourse and framing of trade disseminated either through traditional intermediaries or directly to voters through powerful new modalities of social media like Twitter. First, we can observe a sharp spike in the total number of monthly words dedicated to trade matters in The New York Times that coincided with much of the campaign leading up to the presidential election of Donald Trump on 8 November 2016. In fact, that sizeable focus has remained relatively constant in the years following the election of President Trump. Word count here is a better proxy for coverage of an issue than, say, number of articles as it captures greater length and depth of analysis including through investigative journalism.

97 See e.g. Trump Tweet: Europe has to pay their fair share for Military Protection. The European Union, for many years, has taken advantage of us on Trade, and then they don't live up to their Military commitment through NATO. Things must change fast! 25.11.2018, https://twitter.com/realdonaldtrump/status/ 1066790517944606721.

98 David Autor, David Dorn, and Gordon Hanson, 'The China Syndrome: Local Labor Market Effects of Import Competition in the United States', 103 (6) American Economic Review 2121 (2013).

99 Carl Ciovacco, The National Interest, Understanding the China Threat, November 29, 2018, https:// nationalinterest.org/feature/understanding-china-threat-37502 (visited 22 July 2019). 


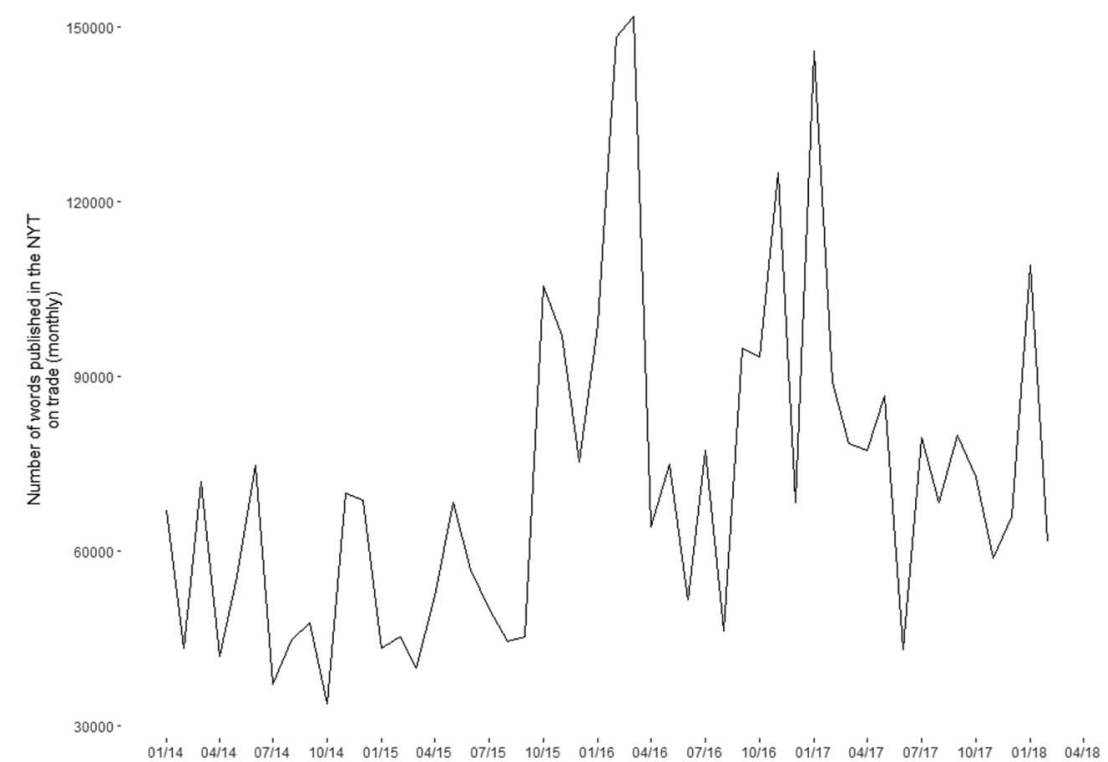

If we next turn to coverage of trade in State of the Union speeches, we can also observe that President Trump is significantly more negative in his sentiments on trade than any of his four predecessors. Given the limited time available for such a speech, whether a President praises or talks negatively about foreign trade can be very revealing. POTUS speeches are also probative as they postdate an election campaign where, typically, newly elected presidents are more willing to offer a more balanced approach on complex questions like trade liberalization. POTUS speeches also have wide viewership and thus can make free trade and/or protectionism salient in the minds of voters. ${ }^{100}$ President Trump here presents trade consistently in a negative frame triggering a range of biases explored earlier, including loss aversion.

100 Using the state of the union sentences data from the 'Comparative Agendas Project US', The Policy Agendas Project at the University of Texas at Austin, 2017. www.comparativeagendas.net. Accessed 26 September 2018, we compared Trump's views on trade with those of the preceding presidents. For doing so, we resorted to sentiment analysis methods-Natural Language Process for extracting expressions of certain sentiments/emotions/opinions from text. Specifically, we took each sentence coded as about 'foreign trade' and measured their sentiment score automatically through a dictionary approach using five different lexicons/algorithms, and by averaging their scores; cf. Finn Å. Nielsen, 'AFINN-96', Department of Informatics and Mathematical Modelling, Technical University of Denmark, http://www2.imm.dtu.dk/ pubdb/views/publication_details.php?id=5981 2010 (visited 22 July 2019); Minqing Hu and Bing Liu, 'Mining and Summarizing Customer Reviews', in Proceedings of the Tenth ACM SIGKDD International Conference on Knowledge Discovery and Data Mining (ACM 2004), 168-177; Saif M. Mohammad and Peter D. Turney, 'Crowdsourcing a Word-Emotion Association Lexicon', 29 (3) Computational Intelligence 436 (2013); Mathew L. Jockers, 'Syuzhet: Extract Sentiment and Plot Arcs from Text', https://github. com/mjockers/syuzhet 2015 (visited 22 July 2019); Tyler W. Rinker, 'Sentimentr: Calculate Text Polarity Sentiment', http://github.com/trinker/sentimentr 2019 (visited 22 July 2019). 


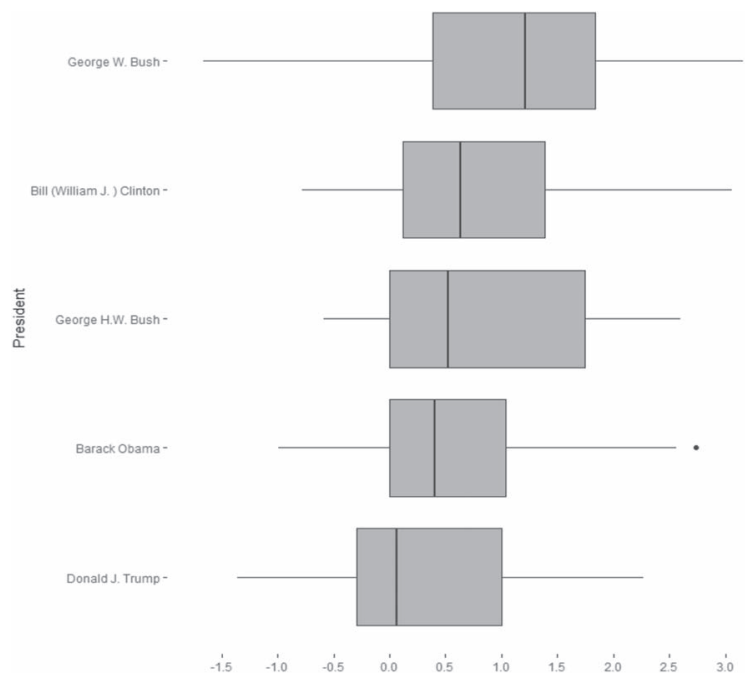

Famously of course, the President also directly interacts with US citizens via Twitter. The time trends below suggest an acceleration from 2013 to a spike in his Tweets about trade and/or China since the end of 2017, reaching its post-election maxima at around the time of the 'Trump Tariffs' in 2018. ${ }^{101}$
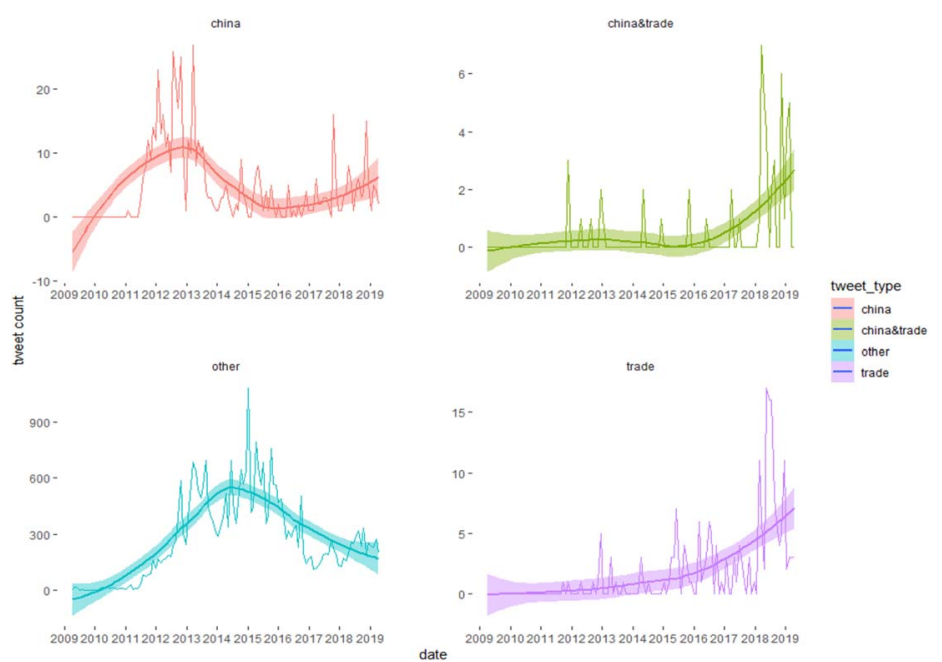

President Trump's attempts at directly communicating with Americans on traderelated matters also seem to have progressively gained traction. For example, the abovementioned spike in his Twitter activity on trade and/or China has been accompanied by

101 We downloaded the population of DJT's tweets from the trump twitter archive (http://www. trumptwitterarchive.com/) and transformed it into a workable dataset. This dataset covers not only the content and relevant metadata of the tweets of the official account of DJT but also other interesting variables for salience, such as retweets and number of 'favorites'. We coded the tweet type classifications, by resorting to regular expression matching. 
an exponential increase in his Tweet's 'retweets' and 'favorite' counts by the American public.

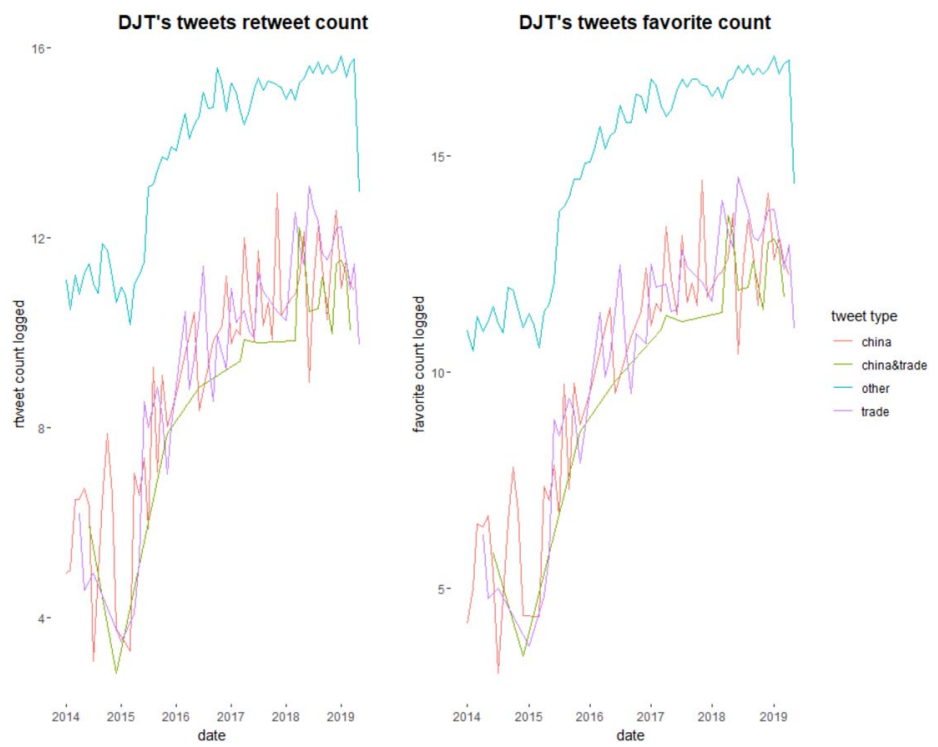

More targetedly, statistics associated with his Twitter activity are tightly correlated with information-seeking behavior on trade matters by Americans, which we proxy using Google search engine data for the search term 'tariffs. ${ }^{\text {. }}{ }^{2}$

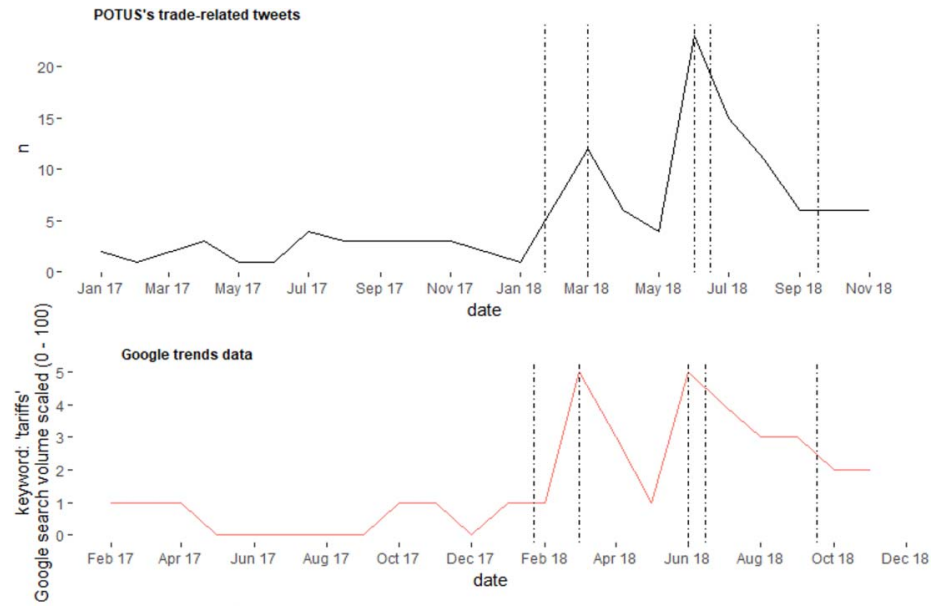

102 Search engine data is often used for proxying issue salience in social science studies. Specifically, google search volumes using 'google trends' (https://trends.google.com/trends/); see KrzysztofJ. Pelc, 'Googling the WTO: What Search-Engine Data Tell Us About the Political Economy of Institutions', 67 International Organization 629 (2013). Our data was collected using the google Trends API. Two datasets were retrieved: a pure time-series data covering the months between 2004 and April 2019 and a geographic dataset covering the campaign/office period (2014 to April 2019), both measuring search volume for the search term 'tariffs'. Google Search volume measurements are scaled on a range of 0 to 100 based on a search term's proportion to all other search terms used in the USA between 2004/2014 and 2019. 
This seems to be particularly true in areas adversely impacted by trade liberalization, such as the so-called 'Rust Belt' states (that generally voted Republican during the last presidential election) and especially during the period of the 'Trump Tariffs' in 2018. ${ }^{103}$

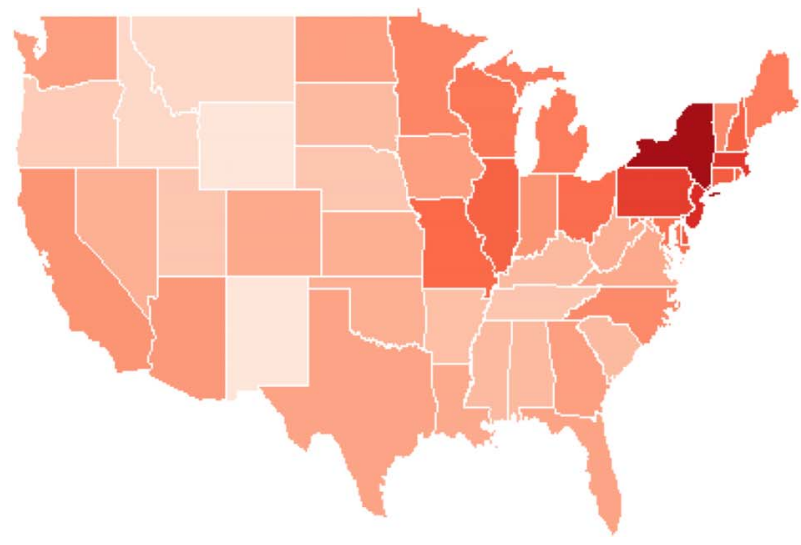

Search term: 'trade' Google search volume logged

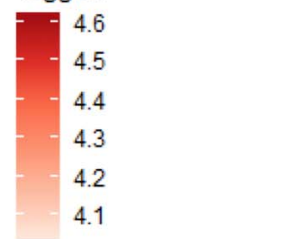

The manner in which these trade and security-focused China articles/tweets has dominated news media and voter perceptions can be contrasted with coverage on technology issues. Economists argue that technological change-both informatic and in terms of automation-is a more important source of decline of manufacturing employment and dislocation effects than trade and trade agreements. ${ }^{104}$ But the stickiness of this principled claim is weakened by the recency, visibility, and style of media coverage on these different phenomena. Job displacement is rarely the singular focus of media attention on technological developments which tend to emphasize the consumer benefits. Populists too rarely campaign directly against technology or automation. If anything, media attention on the negative effects associated with technological shifts focus now far more so on privacy concerns than job displacement. Globalization (particularly trade from China) is a phenomenon that is far more visible (including to political actors) than patterns of technological change and thus much easier to blame for transition challenges. In turn, the costs ascribed to economic globalization can be easily turned into political fodder by anti-market, anti-elite political movements that span the political spectrum. ${ }^{105}$

103 In a similar vein, evidence shows that President Trump's consistent 'China bashing' in his tweets and speeches won him votes in the areas most affected by outsourcing to China. A county-level analysis published in December 2016 found that a one-point increase in import competition from China was associated with a $2.9 \%$ increase in support for Mr Trump relative to earlier Republications. Niall Ferguson and Xiang Xu, 'Trump and the "Chimerica” Crisis,' The Wall Street Journal (6 May 2018) (https://www. wsj.com/articles/trump-and-the-chimerica-crisis-1525635323, visited 20 September 2019).

105 With an instructive example, see Joost Pauwelyn, Andrew Guzman, and Jennifer Hillman, International Trade Law, 3rd ed. (Köln: Wolters Kluwer 2016) 12f. 


\section{Fairness and equity in trade policy}

Fairness concerns have also been explored in trade theory. Experimental studies explore voter behavior if provided with more information about how trade barriers affect the distribution of income. Distributional cues generate two opposing effects. While they make people more likely to express self-serving policy preferences, they also make people more sensitive to the interests of others. In one study, both reactions were evident, but selfish responses outweighed altruistic ones. Thus, if people knew more about the distributional effects of trade, the correlation between personal interests and policy preferences would tighten. The explanatory power of economic self-interest depends therefore on beliefs about causality. ${ }^{106}$

It can also be shown that lower-earning and less-skilled intensive industries tend to receive relatively high levels of trade protection. Indeed, this pattern of protection holds across countries with vastly different economic and political characteristics. One possible explanation is individual inequity aversion leads to systematic differences in support for trade protection across industries. Survey experiments in China and the USA provide strong evidence that individual policy opinions about sector-specific trade protection depend on the earnings of workers in the sector. ${ }^{107}$

Behavioral analysis on ideas surrounding fairness also helps us understand better why particular groups (beyond those who lose in economic terms) are likely to support protectionism. Subjects in experiments do not engage in simple 'pocketbook' voting on trade issues (as rationalist theories predict) but are more likely to take into account perceived sociotropic effects of trade on their community. ${ }^{108}$ Trade protectionism is also closely linked to out-group aversion such that individuals who are averse to outgroups (including foreigners) are less favorable to free trade and inclined to deny the benefits of trade agreements to out-group members. ${ }^{109}$ In a similar vein, Grossman and Helpmann (leading proponents of the classic political economy account of trade) now candidly acknowledge that 'interest groups do not seem to have played a central part' in the dramatic reversal of trade attitudes and trade policies. ${ }^{110}$ Drawing on social psychology, they also explore the notion that voters' preferences over trade policy reflect not only their material self-interest but concerns for members of those groups in society with whom they identify. ${ }^{111}$ Fairness concerns and altruism are thus particular to other members of the group, since individuals predominantly care about the well-being of those they perceive to be similar to themselves. Interestingly, they find that populist revolutions in which the working class repudiates its identification with a broad national

106 See Rho and Tomz, above $\mathrm{n} 68$.

107 Xiaobo Lü, Kenneth Scheve, and Matthew J. Slaughter, 'Inequity Aversion and the International Distribution of Trade Protection', 56 American Journal of Political Science 638 (2012).

108 Edward D. Mansfield and Diana C. Mutz, 'Support for Free Trade: Self-Interest, Sociotropic Politics and Out-Group Anxiety', 63 (3) International Organization 425 (2009).

109 Ibid.

110 Gene M. Grossman and Elhanan Helpman, 'Identity Politics and Trade Policy', NBER Working Paper 25348, p. 1 http://www.nber.org/papers/w25348 (2018), 1. To be sure, identity is not a new notion in economics, starting with George A. Akerlof and Rachel E Kranton, 'Economics and Identity', 115(3) The Quarterly Journal of Economics 715 (2000). 
group that includes the elites and opts instead to identify more narrowly (only with other non-elites) lead to an increased demand for protectionism. ${ }^{112}$ Whereas classic trade theory looks at the utility of a nation as a whole, this may thus have shifted in voters' perception to their in-group. Critically under their model, the trigger event in this shift in identification is a widening of income distribution, 'no matter whether that has been caused by globalization, by technological change or by some other mechanism. ${ }^{\text {, }}{ }^{13}$ This connects back to the rising inequality within countries leading to loss aversion as discussed above.

The inequity aversion and sense of fairness may also play in between countries. The purported unfairness of current trade agreements has been extensively highlighted by President Trump, not only concerning China ${ }^{114}$ but also NAFTA and EU partners. ${ }^{115}$ Even the reactions of trading partners are framed as unfair. ${ }^{116}$ Here, we encounter a sharp difference with public discourse in the USA vis-à-vis the EU. Populism too has infected European policy discussions, especially on issues of migration. Yet European populism does seem to be crudely anti-trade of the sort so visible in the USA nor does it (yet) target select countries like China. Of course, Trump's tariffs are likely to be perceived as 'unfair' by those against whom they are imposed, possibly leading to recursive dynamics that trigger support for protectionism across borders even by the EU. Key domestic groups will support retaliating and standing up for national interests when another country raises tariffs unilaterally. ${ }^{117}$ But it is other aspects of economic globalization and their legal manifestations-especially austerity policies within the Eurozone and investor-state dispute settlement in bilateral investment treaties - that are particularly controversial in European discourse. Few European populist politicians and their political parties openly advocate trade barriers as seen in the US context. In fact, the advocates of BREXIT offer free trade as one of the claimed benefits of exit from the EU, arguing that it would allow them to pursue deeper levels of liberalization through FTAs with third countries. Pointedly, some have suggested that this variance in populist discourse is attributable to the far stronger social protections and welfare provisions in Europe. ${ }^{118}$

Ibid., p. 28.

Ibid.

Trump Tweet: 'China has been taking out massive amounts of money \& wealth from the U.S. in totally one-sided trade but won't help with North Korea. Nice!», 2 January 2017, https://twitter.com/ realDonaldTrump/status/816068355555815424

Trump Tweet: 'Mexico has taken advantage of the U.S. for long enough. Massive trade deficits ....', 27 January 2017, https://twitter.com/realDonaldTrump/status/824970003153842176; 'The U.S. has a 60 billion dollar trade deficit with Mexico. It has been a one-sided deal from the beginning of NAFTA with massive numbers ..., 26 January 2017, https://twitter.com/realDonaldTrump/status/ 824615820391305216.

16 Trump Tweet, 'Harley Davidson has struggled with Tariffs with the EU, currently paying $31 \%$. They've had to move production overseas to try and offset some of that Tariff that they've been hit with which will rise to 66\% in June of 2021'. @MariaBartiromo So unfair to U.S. We will Reciprocate!”, 23 April 2019. https:// twitter.com/realDonaldTrump/status/1120644639311134720.

We would like to thank one reviewer for this observation.

See Rodrik, above n 26, at 6. 
Openness to trade in the European setting has always been directly accompanied by far greater redistribution and social insurance. From an individual's perspective, knowing that those at risk of unemployment or in unemployment fall into a social safety net (as is mostly the case in Europe) may reduce the inequity aversion and thus loss aversion. In fact, more than two-thirds of citizens in the EU think that the EU has benefited their country, with a rising tendency over the last 10 years (though with only $60 \%$ of UK citizens agreeing with this statement). ${ }^{119}$ Indeed, the reasons mentioned for this are the economic gains as well as new work opportunities. ${ }^{120}$ The policy debates within the EU do not therefore put into question the value of freedom of movement of goods, services, or even capital. The large majority of EU citizens have a sense of togetherness in that they think more unites Europe than separates it, and since the BREXIT vote, this has surged in the other EU member states. ${ }^{121}$ The key policy debates within the EU are instead centered around freedom of movement of persons (particularly in the UK) or irregular patterns of migration. Somewhat ironically, the European opposition to immigration and refugees is driven, in part, by concern of erosion in greater access to social benefits. But it offers (even if arguably still insufficient) social benefit security to workers affected by job displacement, whether induced by trade or other causal factors like technology, avoiding the type of inequity aversion possibly at play in the American policy context.

\section{CONCLUSION AND OUTLOOK}

Although some research exists, behavioral political economy in the domain of trade is still in its infancy. Our goal in this paper was to highlight targeted psychological analysis to better understand why current trade policy has become more protectionist in some countries, especially the USA. This is not to suggest that all of these insights are at play in every setting and thus offer perfect explanatory or predictive value. ${ }^{122}$

119 DG Communication, United Kingdom, Socio-demographic trendlines-EP Eurobarometer (20072018), Edition 4 (Octobe r 2018), available at: http://www.europarl.europa.eu/at-your-service/de/beheard/eurobarometer/socio-demographic-trends-in-national-public-opinion-edition-4, (visited 6 May 2019), at 12 and 16.

120 Flash Eurobarometer, Report, Emotions and Political Engagement Towards the EU, 25 April 2019, http:// www.europarl.europa.eu/at-your-service/files/be-heard/eurobarometer/2019/emotions-and-politicalengagement-towards-the-eu/report/en-flash-2019.pdf (visited 6 May 2019), at 12.

121 Flash Eurobarometer, Report, Emotions and Political Engagement Towards the EU, 25 April 2019, http:// www.europarl.europa.eu/at-your-service/files/be-heard/eurobarometer/2019/emotions-and-politicalengagement-towards-the-eu/report/en-flash-2019.pdf (visited 6 May 2019), at 12.

122 Consider for instance the variable of market power and size. The USA is a relatively closed economy (in the sense that much of its output is geared to domestic production and consumption) and therefore may in fact not lose as much from protectionist policies. This is not the case for most countries in the world that have to specialize and thus export if they want to increase per capita incomes (or sustain them), with the latter offering an external constraint on resort to protectionist policies. 
Indeed, in other geopolitical constellations (such as in the EU), factors such as security framing on trade have historically led to to greater integration instead of economic nationalism. Behavioral political economy of trade does not per se predict which way policy preferences will ultimately run. In order to make country-specific predictions, an additional set of scope conditions would need to be defined and applied, not least history, dependency on international markets, perceptions of country or industry status (rising or declining), and whether a given state has a well-developed social security system or an efficient system of redistribution.

But generally speaking, behavioral insights are under-explored variables in trade law scholarship which are potentially highly relevant to understanding current trade policy in some states, especially as they sharply call into question some of the rigid assumptions of the classic political economy account which has hitherto informed international trade law. These sorts of psychological biases and heuristics can provide templates for patterns of conduct in complex settings. Of course, these psychological kinks have always been with us including in past periods of benign or supportive policies on trade. The difference now may be one of critical mass in that geopolitical and distributional constellations have changed in such a way that key politicians play on certain biases, consciously or otherwise.

Loss aversion is certainly probative in understanding the growth of protectionism and levels of voter support for such policies in the USA. The Trump Administration has consistently invoked a double loss frame of the role of trade in the USA, painting it as both an individual loss for working Americans (through trade-induced labor displacement feeding into fairness concerns surrounding growing levels of inequality within the USA) and as a national loss for the USA as a country (given rising levels of equality between the USA and other countries such as China). The behavioral consequences of the double loss bias have been accelerated even further by the active deployment of a negative security frame in debates surrounding trade policy. The aggressive notion that broad patterns of trade now threaten the national security of the USA is the most unprecedented departure from past American understandings of the trade and the international trade law system. These changes (largely Trump-induced) have seemingly made Americans more protectionist and risk-acceptant to US entry into trade wars. Principled and empirical objections pointing to the causative contribution of other factors (such as technology-induced labor displacement) are likely to have little traction in policy debates given availability bias and the aggressive negative framing of trade through conventional media intermediaries and powerful new modalities of social media such as Twitter. Indeed, this direct channel of communication between politicians and voters may necessitate trade theory to rethink the role of lobbying in trade policy.

International economic lawyers should be aware that trade is now inherently more vulnerable as a policy agenda. Legal structures in trade law need to be re-orientated away from a rational choice account (on which they are currently premised) to better reflect the vulnerabilities highlighted by a behavioral economy analysis. Most importantly, we can no longer separate international trade law from larger debates around globalization or domestic policy especially on questions of inequality and social inclusion measures. 
To be sure, the national plane would seem to be the primary focus of dealing with current deficiencies which are conducive to exploiting biases and heuristics of voters. ${ }^{123}$ Patterns of inequality that can bleed into fairness concerns raise complex questions of the appropriate levels of a social safety net as well as retraining and employment opportunities. The aggressive unilateralism of deployment of tariffs by the US Executive also raises a question of the sufficiency of veto points/players as a matter of US law and domestic law reform. ${ }^{124}$ International trade law too must play its part. Current WTO disciplines, such as in the Agreement on Agriculture or the Agreement on Subsidies and Countervailing Measures, should not act as a constraint on domestic social inclusion measures. ${ }^{125}$ Of course, properly interpreted, existing WTO law can support legitimate domestic measures which are necessary for social inclusion and poverty reduction by respecting them under GATT Article XX(a). ${ }^{126}$ Legal imagination though can and should extend beyond existing WTO norms, identifying and diagnosing reform models to build sustainable levels of public support for international disciplines on domestic trade policy. 127

123 Bounded rationality is of course also a constitutional rather than only an economic and trade policy problem requiring inclusive, constitutional restraints (e.g. prescribing non-discriminatory competition rules, 'protection balance sheets' publicly justifying redistributive economic legislation, legal, and judicial remedies of adversely affected citizens, structural adjustment assistance rules): see for details Meinhard Hilf and Ernst-Ulrich Petersmann (eds), National Constitutions and International Economic Law (Deventer: Kluwer, 1993); Heinz Hauser and Ernst-Ulrich Petersmann (eds), International Competition Rules in the GATT/WTO System, Special Issue of the Swiss Review of International Economic Relations (1994).

124 On veto points/players, see George Tsebelis, Veto Players: How Political Institutions Work (Princeton: Princeton University Press, 2003).

125 Request for consultation Australia and Brazil, India-Measures Concerning Sugar and Sugarcane, WT/DS579/1 and WT/DS580/1, 5 March 2019.

126 Gillian, A Moon, “Fundamental Moral Imperative”: Social Inclusion, the Sustainable Development Goals and International Trade Law After Brazil-Taxation', 52 Journal of World Trade 995 (2018).

127 See, e.g. Gregory C. Shaffer, 'Retooling Trade Agreements for Social Inclusion' (2019) (1) University of Illinois Law Review 1; David Trubek, Chantal Thomas, and Alvaro Santos, 'World Trade and Investment Law in a Time of Crisis: Distribution, Development and Social Protection', University of Wisconsin Law School, Legal Studies Research Paper Series No. 1470 (2019). 